\title{
NECROTIC AND COMMON STRAINS OF POTATO VIRUS Y AND RESISTANCE OF PLANTS NICOTIANA TABACUM L. AND NICOTIANA RUSTICA L.
}

\author{
Taran Oksana ${ }^{1}$, Lisovyy Mykola ${ }^{1}$, Savina Olena ${ }^{2}$, Mishchenko Lidiya ${ }^{3}$ \\ ${ }^{1}$ National University of Life and Environmental Sciences of Ukraine, Kyiv, Ukraine \\ ${ }^{2}$ Uzhhorod National University, Uzhhorod, Ukraine \\ ${ }^{3}$ Taras Shevchenko Kyiv National University, Kyiv, Ukraine
}

\begin{abstract}
Research on the resistance of cultivars of tobacco plants Nicotiana tabacum L. and Nicotiana rustica L. under conditions of artificial infection with necrotic and common isolates Potato virus Y (PVY). Molecular biological characteristics of Potato virus $\mathrm{Y}$ isolates were established by means of transmission electron microscopy, multiplex reverse polymerase chain reaction and ELISA. Biological characteristics of isolates were investigated by indicator plant's method. The plant resistance of cultivars of tobacco to PVY isolates was investigated by artificial inoculation followed by visual detection of symptoms of infection and virus detection by transmission electron microscopy and ELISA. Studies of extracted from potato plants isolates showed that they belong to different strain groups in response to their infection, which developed in the indicator plant Nicotiana bentamiana Domin and Nicotiana tabacum var. Samsun. Multiplex RT-PCR confirmed availability of isolate Potato virus $Y$ and the absence of other viruses that infect potatoes. Discovered different reactions tobacco plants var. Samsun 155 and Sobalchskyy 34/40 on inoculation of common and necrotic isolates of Potato virus Y. Plants of these cultivars respond at inoculation of necrotic isolate formation of systemic necrosis that were similar to the symptoms that caused this isolate to indicator plants. At inoculation of common isolate visible symptoms in plants of these cultivars were not observed, but the methods of transmission electron microscopy and ELISA confirmed the accumulation of the inoculated plants virions of Potato virus Y. However, there were no visible symptoms on inoculation with both isolates of plants Nacotiana rustica cultivars Matsui Field and Actec, and plant Nicotiana tabacum, variety Sobalchskyy 193. The plants cultivars Samsun 155 and Sobalchskyy 34/40 showed reaction tolerance relatively common isolate because the virus accumulates in them in large quantities in the absence of visual symptoms. However, these cultivars are susceptible to infection of the necrotic isolate of PVY. The absence of symptoms in plants Nacotiana rustica and tobacco cultivar Sobalchskyy 193 may indicate as tolerant reaction, and the presence of resistance to both isolates. Given the high harmfulness Potato virus $Y$ and its wide spread in Ukraine, further studies are needed to identify the type of tobacco plant resistance that will make it possible to identify new sources of resistance to this pathogen.
\end{abstract}

Keywords: tobacco; resistance; Potato virus Y; necrotic isolate; common isolate

\section{Introduction}

Potato virus Y (PVY) - the member of the genus Potyvirus family Potyviridae, that can infect potato, tomato, tobacco, pepper and other plants of the Solanaceae family. The strains can be determined by the symptoms that occur in host plants, potatoes and tobacco, as well as by serological reactions of

\footnotetext{
*Corresponding author: Oksana Taran, National University of Life and Environmental Sciences of Ukraine,
} Kyiv, Ukraine, $₫$ okstar@ukr.net 
selected isolates. Currently, there are about nine groups of detected strains, but the most basic and common until recently considered are three groups of strains, namely: $\mathrm{PVY}^{\mathrm{N}}$, $\mathrm{PVY} \mathrm{Y}^{\mathrm{O}}$ and $\mathrm{PVY} \mathrm{C}^{\mathrm{C}}$ (Tribodet et al., 2005).

Isolates belong to group of $\mathrm{PVY}^{\mathrm{N}}$ cause severe symptoms of necrosis of veins in the tobacco plant (Nicotiana tabacum L.), and in the field can lead to a significant deterioration in the quality of products of this culture. At the global level, Potato virus $\mathrm{Y}$ is certainly the most damaging virus of tobacco. The latest survey of CORESTA (Cooperation Centre for Scientific Research Relative to Tobacco) on tobacco viruses confirms this situation. Losses due to necrotic strains of the virus are increasing in many countries. The influence of this virus on Burley and Virginia tobacco are reduction of size and weight of leaves, plant height, and yield. The earlier the infections occur, the greater the impact on the tobacco crop. In Chile and New Zealand, heavily infected crops have experienced yield reductions exceeding 70\%. The chemical quality of harvested tobacco is reduced also in the presence of PVY. An increase of nicotine, nornicotine, total nitrogen, nitrogen-insoluble acid and nitrate content can be observed (Marchoux et al., 2008; Иваницкий и др., 2012).

To meet the certain needs of breeding, the works on to identifying the variety groups with stable resistance under fierce natural and artificial infectious background should be done in respect to get the expected effect of the source resistance. Great importance is raising new varieties of group stability. For successful breeding in this area required starting material with resistance group to defeat pathogens that would fully meet the increasing demands on breeding performance and high level of adaptability to adverse environmental factors. Therefore, the study of varieties with a view to providing new sources of resistance to major pathogens remains relevant and necessary (Савина, 2013).

Moreover, the research of PVY strain has important issues regarding the interaction of virus and host plant. A plant's reaction on the stress, caused by infection, leads not only to ensure its survival, but causes changes in virus populations that have long-term consequences. The emergence of new variants of the pathogen influenced by intracellular factors of host often occurs in the presence extensive quantity of ordinary members of the population. This does not enable initially find these new variants. But in the future the situation may change. In view that the rate of mutation of RNA viruses evaluated in order one mutation per genome replication, can assume that most of the viral particles in the infected host may represent a unique genotypes (Tian et al., 2013). Thus, these studies help to estimate the dynamics of populations and identify new isolates of PVY that have new characteristics and genomic structures (Chikh et al., 2008; Zhimin et al., 2012).

\section{Materials and methodology}

In our studies we were evaluated the resistance of plants Nicotiana tabacum cultivars: Samsun 155, Sobalchsky 34/40, Sobalchsky 193 and N. rustica varieties: Matsui Field and Actec to necrotic and common isolates of PVY. Isolates were selected in the field of potato plants that cultivated in the Kyiv region, Ukraine. Belonging of the isolates to a group of PVY strains were determined by biological tests on plants Nicotiana bentamiana Domin and Nicotiana tabacum, var. Samsun.

Indicator plants and experimental plants Nicotiana tabacum and Nicotiana rustica L. were grown in a greenhouse at a temperature of $25^{\circ} \mathrm{C}$ and 16-hour light period. We used tobacco plants to test at the age of 4-6 leaves. Were inoculated five plants per variety with sap of infected plants in the solution $1: 2$ in the phosphate buffer saline (PBS, pH 7,4). Mock-infected plants were treated with PBS $(\mathrm{pH} 7,4)$. The plants investigated by means DAS-ELISA, RT-PCR and transmission electron microscopy. 
The isolates were tested serologically using polyclonal antibodies for PVY, Potato virus M (PVM) and Potato leaf roll virus (PLRV) (LOEWE ${ }^{\circledR}$ Biochemica $\mathrm{GmbH}$, Germany). Total RNA was isolated from $5 \mathrm{~g}$ of whole leaf tissue using the procedure as described by Boom et al. (1990). Multiplex RT-PCR, which included the definition of PVY, PVM, PVS, PVX, PLRV and Potato spindle tuber viroid, carried out as described (Мельничук et al., 2005). We used commercial kits for RT-PCR of production AmpliSens, (Russian Federation).

For determine the viruses by DAS-ELISA using polyclonal serum to the complex strains of PVY, which includes antibodies $P V Y^{O}$ and $P Y^{N}$, as well as diagnostic tools for determining Potato virus M (PVM) and Potato leaf roll virus (PLRV) (LOEWE Biochemica GmbH, Germany). Results were recorded at wavelengths of 405/630 nm using a reader Termo Labsystems Opsis MR (USA) and software Dynex Revelation Quicklink (Mishchenko et al., 2011). Data processing optical density of the samples was performed using descriptive statistics, to determine the average value and standard deviation.

Optical density threshold that distinguishes the positive results of the enzymatic reaction on the value of the background, was determined for each board individually, as recommended (Gugerli, 1986). Morphology of viral particles in plants potatoes and tobacco were investigated by transmission electron microscopy using a microscope JEM 1230 (JEOL, Japan). We used negative contrasting of preparations potato plants and tobacco $2 \%$ solution of phosphotungstic acid or $2 \%$ solution of uracil acetate for 2 minutes (Салига, Снітинський, 1999).

\section{Results and discussion}

PVYN isolate caused systemic necrosis symptoms on plants indicators. Necrosis developed on leaf tissue between the veins as a light brown spots, which eventually increased to small light brown

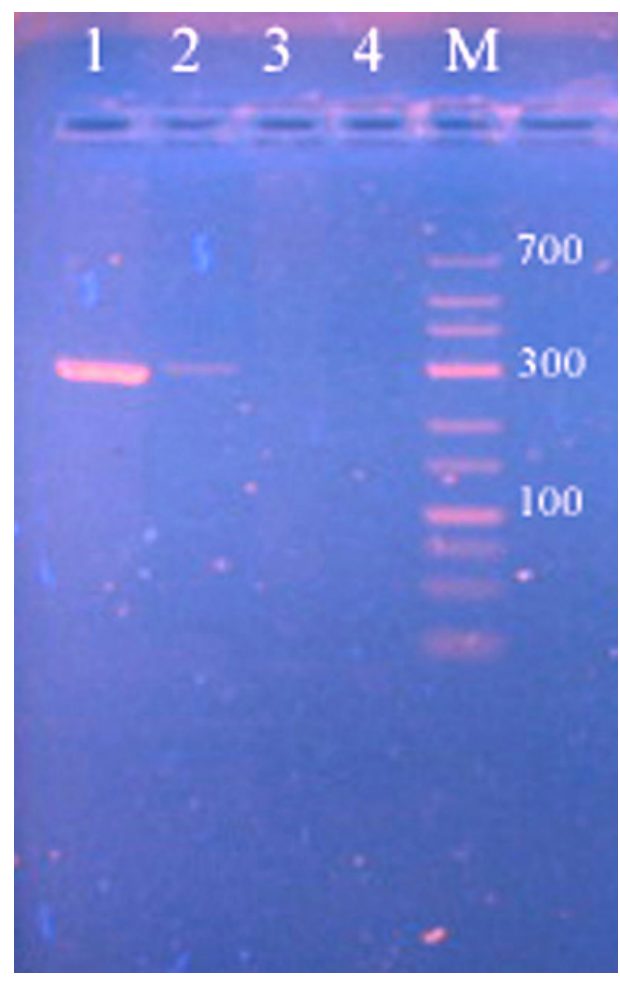
necrotic spots. At stems also appeared necrotic light brown stripes. The leaves with necrosis after 11-12 days of inoculation wilted, wilting begins with the basal part of the leaves and the edge of the leaf blade. The leaves are withered, in some cases the plants died. These symptoms are characteristic to infection of necrotic strains of PVY (Tribodet et al., 2005). In indicator plants that inoculated isolate $\mathrm{PVY}$ have not found out noticeable symptoms of infection. In general, the infection caused only mild mosaic and some deformation of the tissue between the veins. Finally, symptoms of mosaic disappeared. This reaction of plants to PVY infection are typical for common isolates of virus (Tian and Valkonen, 2013).

Figure 1

The results determine of the cDNA to RNA segments of PVY, PVM, PVS, PVX, PLRV and Potato spindle tuber viroid in samples Nicotiana benthamiana, infected $\mathrm{PVY}$ and $\mathrm{PVY} \mathrm{N}^{\mathrm{N}}$

Tracks 1-2: amplification products PVY (365 bp), PVS (213 bp), PVX (411 bp). Tracks 3-4: amplification products PVM (276 bp), PLRV (300 bp), PSTV (150 bp); $\mathrm{M}$ - marker. The samples of isolate $\mathrm{PVY} \mathrm{P}^{\mathrm{O}}$ are on tracks 1 and 3. The samples of isolate PVY ${ }^{\mathrm{N}}$ are on tracks 2 and 4 
DAS-ELISA found antigens of PVY in the samples of indicator plants, other viruses are not detected. Products amplification of CDNA of PVY capsid gene were found by multiplexed RT-PCR in samples of indicator plants Nicotiana benthamiana, which were inoculated $P V Y^{N}$ and $P V Y^{O}$ isolates from potato plants (Figure 1).

Thus, used isolates of PVY, belonging to different groups of strains and didn't contain other viruses. Research of response of plants Nicotiana tabacum and Nicotiana rustica to inoculation of selected isolates revealed the following. When inoculated tobacco plants varieties Samsun 155 and Sobalchskyy $34 / 40$ with the isolate of $P V Y^{N}$ appeared symptoms of vein necrosis in the basal part of the leaf blade. Further necrosis spread to the petioles, sometimes on stalks of plants. The first indication of virus infection on plants of var. Samsun 155 found in 9 day after inoculation as a clarification of the veins of young leaves. Systemic necrosis quickly spread by leaf veins, causing wilting and drying of leaf blade. Part of plants of this cultivar died 30 days after inoculation. Inoculation of tobacco Nicotiana tabacum var. Sobalchskyy 34/40 plants with isolate PVY ${ }^{N}$ also led to the emergence of necrosis of veins, but infection didn't lead to death of the plant. Plants infected with necrotic virus's isolate, were developing for a long time, appeared symptoms of necrosis on the young leaves was the evidence of systemic infection.

Thus, the inoculation of tobacco plants discovered different reactions to inoculation common and necrotic isolates of PVY.

Inoculation of plants Nicotiana rustica, cultivars Matsui Field and Actec and plants tobacco variety Sobalchskyy 193 didn't cause any visible symptoms of infection (Table 1).

Table 1 Results of varieties tobacco plants inoculation by necrotic and common isolates of PVY

\begin{tabular}{|l|c|c|}
\hline Species/variety & \multicolumn{2}{|c|}{ PVY isolates } \\
\cline { 2 - 3 } & PVY $^{\mathbf{N}}$ & PVY $^{\text {N }}$ \\
\hline Nicotiana tabacum, var. Samsun $\mathbf{1 5 5}$ & $\mathrm{NV}, \mathrm{M}$ & no symptoms \\
\hline Nicotiana tabacum, var. Sobalchsky 34/40 & NV, M & no symptoms \\
\hline Nicotiana tabacum, var. Sobalchsky 193 & no symptoms & no symptoms \\
\hline Nicotiana rustica, var. Matsui Field & no symptoms & no symptoms \\
\hline Nicotiana rustica, var. Actec & no symptoms \\
\hline
\end{tabular}

NV - necrosis veins; $M$ - mosaic; MM - mild mosaic

Thus, the results of laboratory tests showed that the cultivars of tobacco Nicotiana tabacum (Sobalchsky 193) and Nicotiana rustica (Matsui Field and Actec) may have resistance to necrotic isolate of PVY.

Significant spread of PVY cultivated plants today attracts the attention of researchers, as the virus is one of the ten most damaging plant viruses. Especially dangerous is the virus strains that cause severe symptoms in host plants. According to studies conducted in Chernihiv region of Ukraine, potato plantations necrotic PVY strains are common in recent years, even discovered samples of infected PVY ${ }^{\text {NTN }}$ strain, which is the most dangerous to the potato culture (Шевченко, 2006). The emergence of new strains of the virus was recorded over the last decade in many countries (Nie and Molen, 2015). Obviously, changes in the populations of the virus in our country meet the global trend of changes in the structure of strains of PVY. This leads to in-depth study of both the pathogen 
and its infection reactions in plants - hosts. The use of genetically resistant plants is one of the most efficient, durable and commonly used strategies to combat viral infections in the field. For centuries, this method helped create plants with high economic qualities, combined with the absence of symptoms (Nicaise, 2014).

\section{Conclusions}

However, today the program of improvement of plants can benefit from the study of interactions between plants and viruses for the creation of resistant cultivars, suitable for use in agriculture. Detection of our varieties of tobacco that are tolerant to infection severe necrotic PVY virus isolate, makes it possible to use them to create new forms of tobacco and conduct directed selection for resistance to the culture of this dangerous pathogen. Also, our studies provide an opportunity to further study and establish mechanisms of resistance identified tobacco plants that expand knowledge in this area.

\section{References}

Boom, R., Sol, C., Salimans, M., Jansen, C. 1990. Rapid and simple method for purification of nucleic acids. J. Clin Microbiol., vol. 28, p. 495-503. https://www.ncbi.nlm.nih.gov/pmc/articles/PMC269651/.

Chikh, A., Maoka, T., Natsuaki K. 2008. Whole genome sequence and characterization of a novel isolate of PVY inducing tuber necrotic ringspot in potato and leaf mosaic in tobacco. J. Phytopathology, vol. 156, p. 413-418. DOI: 10.1111/j.1439-0434.2007.01377.x

Gugerli, P. Potato viruses. 1986. Bergmeyer HU, editor. Methods of enzymatic analysis, Antigens and antibodies 2. VCH Verlagsgesellscaft mBH, Germany, p. 430-446. ISBN 978-0895732330.

Marchoux, G., Gognalons, P., Sélassié K. 2008. Virus des solanacées: du génome viral à la protection des cultures. Versailles: Quae, 896 p. ISBN 978-2-7592-0076-4.

Mischenko, L., Polischuk, V., Taran, O., Gordeychik, O. 2011. Viral infection of potato and ifectivity course in simulated vicrogravity. Ukrainian, Kyiv: Fitosotsiotsentr, 137 p. ISBN 978-966-306-020-4.

Nicaise, V. 2014. Crop immunity against viruses: outcomes and future challenges. Front Plant Sci, vol. 5, p. 661-678. doi: 10.3389/fpls.2014.00660

Nie, X., Molen, T. 2015. Host recovery and reduced virus level in the upper leaves after Potato virus $Y$ infection occur in tobacco and tomato but not in potato plants. Viruses, vol. 7, no. 2, p. 680-698. DOI: 10.3390/v7020680.

Singh, R., Valkonen, J., Gray, S., Boonham, N. 2008. The naming of Potato virus Y strains infecting potato. Arch. Virol, vol. 153, p. 1-13. DOI: 10.1007/s00705-007-1059-1

Tian, Y., Valkonen, J. 2013. Genetic determinants of Potato virus $Y$ required to overcome or trigger hypersensitive resistance to PVY strain group O controlled by the gene Ny in potato. Mol Plant Microbe Interact., vol. 26, no. 3, p. 297-305. DOI: 10.1094/MPMI-09-12-0219-R

Tribodet, M., Glais, L., Kerlan, C., Jacquot, E. 2005. Characterization of potato virus Y (PVY) molecular determinants involved in the vein necrosis symptom induced by $P V Y^{N}$ isolates in infected Nicotiana tabacum cv. Xanthi. J Gen Virol., vol. 86, p. 2101-2105. DOI: 10.1099/vir.0.80926-0

Zhimin, Y., Chrzanowska, M., Michalak, K., Zagórska H., Zimnoch-Guzowsk, E. 2012. Recombinants of PVY strains predominate among isolates from potato crop in Poland. Journal of Plant Protection Research, vol. 52, no. 2, p. 214-219. DOI: 10.2478/v10045-012-0033-4.

Иванитский, К., Виноградов В., Борисова И. 2012. Реакция сортов табака мировой коллекции на поражение болезнями в полевых условия. AGROXXI, № 4, p. 11-13. https://www.agroxxi.ru/ journal/20130709/20130709.pdf 
Мельничук, М., Антіпов, І., Спірідонов, В., Мельничук С.Д. 2005. Розробка діагностичних тестсистем на виявлення вірусів картопляної групи методом полімеразної ланцюгової реакції. Аграрна наука і освіта, вип. 6, № 1-2, p. 5-8. http://nd.nubip.edu.ua/2011_6/11aio.pdf

Салига Ю., Снітинський В. 1999. Електронна місроскопія біологічних об'єктів. Львів : Світ. 152 р. ISBN 966-603-036-5.

Савіна О. 2013. Оцінка основної колекції на стійкість проти хвороб тютюну. Агробіологія, № 10, p. 53-57. http://nbuv.gov.ua/UJRN/agr_2013_10_15

Шевченко О. 2006. Розповсюдження та діагностика некротичних штамів Ү-вірусу картоплі на Поліссі України. Вісн. ХНАУ. Сер. "Рослинничтво, селекція, насінництво, овочівництво", № 5, р. 110-115. http://www.sg-microb.ho.ua/arh/pdf15-16/SM15-16_13.pdf 